\title{
MEL-net: Rede de Pesquisa sobre Muçulmanos em Espaços Lusófonos ${ }^{\mathrm{NE}}$
}

Nina Clara Tiesler Universidade de Lisboa
O terceiro encontro da Rede de Pesquisa sobre Muçulmanos em Espaços Lusófonos (MEL-net) foi realizado de 28 a 30 de novembro de 2006 durante o IX Congresso Luso-Afro-Brasileiro de Ciências Sociais, na Universidade Agostinho Neto, em Luanda, Angola. Seis pesquisadores do Brasil, Angola e Moçambique apresentaram trabalhos sobre a história e desenvolvimentos recentes do Islã nesses países. O tema do encontro, organizado por Lorenzo Macagno (Universidade Federal do Paraná, Brasil), Nina Clara Tiesler (Instituto de Ciências Sociais, Universidade de Lisboa, Portugal) e Fátima Viegas (Universidade Agostinho Neto, Luanda, Angola), foi “O Papel das Comunidades Muçulmanas nos Processos de Desenvolvimento e Modernização em Sociedades Lusófonas".

A presença de comunidades islâmicas em Angola é um fenômeno muito recente e a pesquisa acadêmica sobre o tema está apenas começando. Somente nos últimos anos muçulmanos de países da África subsaariana, sobretudo Mali, Nigéria e Senegal, migraram para Angola, estabelecendo-se principalmente em Luanda. Um primeiro relato sobre comunidades muçulmanas em Luanda foi apresentado por Fátima Viegas, que também convidou representantes de comunidades locais. Eles expuseram sua luta por reconhecimento e convidaram os pesquisadores a visitar duas das oito mesquistas existentes na periferia da cidade, ainda parcialmente inacabadas porque a construção foi interrompida em virtude de obstáculos burocráticos.

A participação de representantes de comunidades islâmicas locais enriqueceu o encontro, distinguindo-o dos que haviam ocorrido anteriormente em Lisboa (III Congresso da Associação Portuguesa de Antropologia, abril de 2006) e em Strasbourg, França (XIX Congresso da AFEMAN - Association Française pour L'Étude du Monde Arabe et Musulman, julho de 2005), onde a MEL-net foi constituída oficialmente e houve a designação de seu Comitê Executivo para 2005/2006 (ver 
acadêmico entre pesquisadores que trabalham com questões relativas ao Islã e muçulmanos em países de língua portuguesa e/ou sobre muçulmanos falantes de português que residem em outros países.

\section{MUÇULMANOS EM PAÍSES DE LÍNGUA PORTUGUESA}

Os muçulmanos são cidadãos e membros ativos da sociedade em praticamente todas as áreas lusófonas. Entre os países africanos falantes de português, Guiné Bissau e Moçambique têm populações muçulmanas longamente estabelecidas, enquanto Angola, por exemplo, recebeu imigrantes dos países de maioria islâmica apenas recentemente. A presença islâmica em Portugal remonta a Gharb al-Andaluz, mas as comunidades muçulmanas contemporâneas não têm nenhum vínculo sócio-demográfico direto com a presença muçulmana histórica na Península lbérica, podendo antes ser compreendidas como um fenômeno pós-colonial. Brasil, Timor Leste e Macau também têm experiências históricas particulares e diferentes populações muçulmanas no presente.

Não obstante as significativas diferenças, os muçulmanos em espaços lusófonos compartilham alguns pontos de comparação sócio-cultural, conforme expressam as questões de pesquisa daqueles que trabalham com essas populações. Nos diferentes contextos, os muçulmanos são tratados como representantes de uma minoria religiosa (essa situação se modificou recentemente na Guiné-Bissau); e, em muitos casos, os muçulmanos representam origens étnicas distintas daquelas da sociedade dominante. Além disso, a migração internacional produz alterações em todos os campos lusófonos, conduzindo freqüentemente a uma crescente diversificação das comunidades muçulmanas. Na esteira das migrações recentes e das tecnologias de comunicação, novos vínculos transnacionais têm emergido entre muçulmanos. Tais vínculos se baseiam muitas vezes em referências compartilhadas a pessoas e lugares deixados para trás, em experiências similares relativas a contextos sócio-históricos nacionais, locais e coloniais do passado e do presente, na etnicidade ou na língua comum - que, em muitos casos, é o português.

\section{A REDE}

A MEL-net está sediada no Instituto de Ciências Sociais da Universidade de Lisboa (ICS-UL) desde 2005. Seu propósito é promover o intercâmbio acadêmico internacional e interdisciplinar e abrir os discursos lusófonos sobre questões relativas aos muçulmanos à comunidade acadêmica mais ampla por meio da organização de encontros, palestras, grupos de trabalho e publicações impressas e eletrônicas. A rede coordena e divulga o MELmail (informativo eletrônico), o MEL-doc (grupo de pesquisas de mestrado/doutorado), o MEL-pub (programa de publicações) e o MEL-site, no qual pesquisadores podem publicar trabalhos em andamento e descrições de seus projetos de pesquisa. Entre outras atividades, a MEL-net está atualmente ampliando sua base de dados bibliográficos sobre muçulmanos em áreas lusófonas, que será disponibilizada em seu site. A primeira publicação impressa, 
uma coletânea de artigos elaborados a partir de comunicações debatidas nos primeiros encontros da MEL-net, será lançada em maio de 2007: uma edição especial da revista acadêmia trilíngüe - francês, inglês e português - Lusotopie (Brill), "Islam en Lusophonie", vol. XIV (1).

Nesse meio tempo, o MEL-mail chegou a cerca de duzentos assinantes cadastrados, 35 pesquisadores internacionais contribuíram de várias formas com a MEL-net e se comprometeram com a consolidação desta nova rede interdisciplinar de pesquisa, que pretende integrar e conectar mais pessoas que trabalhem com questões relativas ao Islã e a muçulmanos em Portugal, Brasil, Angola, Moçambique, Guiné Bissau, Cabo Verde, Macau e Timor Leste, assim como em Goa, Damão e Diu.

\section{Contatos}

mel-net@ics.ul.pt,www.mel-net.ics.ul.pt

\section{Comitê Executivo MEL-net 2005/2006}

Nina Clara Tiesler (ICS, Universidade de Lisboa), AddoolKarim Vakil (King's College, Londres), Paulo Daniel Farah (Centro de Estudos Árabes, Universidade de São Paulo), Maria Abranches (CIES/ISCTE, Lisboa).

\section{Encontros da MEL-net}

\section{Luanda, 28 a 30 de Novembro de 2006}

“O Papel das Comunidades Muçulmanas nos Processos de Desenvolvimento e Modernização em Sociedades Lusófonas" (em português)

Patrícia Santos Schermann (UFSC) - Reverenciado Khartum: saber e orientação religiosa de muçulmanos convertidos ao Islão no Brasil

Paulo Daniel Farah (USP) - Acerca da Representação dos Muçulmanos na Bibliografia Brasileira e da Padronização de Termos Vinculados ao Islã (apresentado por Patrícia Schermann)

Ibrahimo Sumaré (comunidade islâmica de Luanda) - O Islã e as Culturas Africanas

Lorenzo Macagno (UFPR) - Novos Intelectuais e Porta-Vozes do Islã em Moçambique

Ali Assaad (Universidade Agostinho Neto, Luanda) - A Origem do Islã e suas Diferentes Correntes"

Fátima Viegas (FLCS/ISCED - Universidade Agostinho Neto, Luanda) - A Expansão Religiosa e Cultural Islâmica em Angola

\section{Lisboa, 6 a 8 de abril de 2006}

“História e Presença Contemporânea de Muçulmanos em Espaços Lusófonos: perspectivas e desafios para a pesquisa acadêmica" (em português) 
Nina Clara Tiesler (ICS-UL), Maria Abranches (ISCTE/CIES) \& José Mapril (ICS-UL) - Apresentando a MEL-net Rita Gomes Faria (Universidade Aberta de Madrid - UAM) - Participação Marroquina na Construção da Comunidade Muçulmana: aproximação aos casos português e espanhol

Maria Abranches (CIES/ISCTE, Lisboa) - Pertenças Reconstruídas: especificidades femininas da presença muçulmana em Portugal

Adriana José Oliveira (Faculdade de Artes da Universidade do Porto) - A Comunidade Muçulmana do Porto Nina Clara Tiesler (ICS-UL) - Estudando Minorias Muçulmanas: islamização dos discursos e perspectivas críticas Lorenzo Macagno (UFPR) - Islã e Política no Norte de Moçambique: reflexões sobre a trajetória de Yussuf Arab

\section{Strasbourg, 7 a 9 de julho de 2005}

"Muslims in Lusophone Spaces" (em inglês e francês)

AbdoolKarim Vakil (King's College, Londres) - (Good) Muslims: Islam, discourses and identities in the Portuguese context

Eduardo Costa Dias (CIES-ISCTE, Lisboa) - De la Guinée-Bissau au Portugal: un itinéraire de construction d'une nouvelle identité musulmane?

Maria Abranches (CIES-ISCTE, Lisboa) - Muslim Women in Portugal: strategies of identity (re)construction

Nina Clara Ties/er (ICS, Universidade de Lisboa) - Lusophone Muslims in Portugal: Religion, Collective Subjectivity, and Shifting Perceptions of Home and Belonging

Paulo Daniel Farah (Centro de Estudos Árabes - USP) - Muslim Presence in Brazil: histories and representations Alvaro Nobrega (ISCSP-UTL, Universidade Técnica de Lisboa) - The Electoral Behaviour of Guinean-Bissau Muslims

NE Texto recebido originalmente em inglês. Tradução de Ciméa B. Bevilaqua. 